Initial Potency.

During the three years ending December, 1911, I examined 23 samples of tincture of digitalis, freshly made by ehemists of repute. The standard employed was that 3 minims of the tincture should kill a frog weighing 20 grams within forr hour's.

Only male frogs were useck, as the weight of ova may vitiate results. Of the 23 samples 12 were of average potency, 6 were under the average and 5 were over the arerage strength. The actual strength of each may be indicated by stating the dose equivalent to the maximum pharmacopoeial dose of 15 minims.

$$
\begin{aligned}
& \text { Average potency... } 12 \\
& \text { Under average } \ldots 6-25: 221: 221: 22 \frac{1}{2}: 20: 18 \text { minins. } \\
& \text { Over average - ... } 5-10: 9: 8: 7: 4 \text { minims. } \\
& \text { Total ‥ } 23
\end{aligned}
$$

Since these varying results are obtained by manufacturers who are anxious to produce drugs of standard potency it would be of interest to know what kind of tinctare is made by tims who aim at nothing more than keeping within the letter of the law as laid down in the Pharmacopoeia. It is to be noted that, in the case of tincture freshly made by firms of repute, the greater danger is likety to arise from the king being too strong.

\section{Kceping Propertics.}

Many estimates of the keeping properties of digitalis have been made. In most of these the initial criterion of potency has been care in mannfacture or the reputation of the manulacturer. As already pointed out, this may not be a satisfactory test, and the value of the present results hies in the fact that the siniples were all tested when fresh. Moran ${ }^{2}$ found that" a tineture "nade by a reliable firm of chemists from earefully dried leaves of good quality should retain its activity for two or three years. Haynes found that tincture-ef digitalis wenk keep for two years withont material change in activity. H His samples were kept in the dark. Other observers have found deterioration in two years' time, others in one year, and yet other's in nine months.

The conditions under which my specimens have been kept were by no means specially favourable; They were not protected from tight, and while the room in which they were stored was lreated during the daytime for part of the year, they were subject to the variat:ons of temperature of the Edinburghr chimate durivg acadenic vacations.

The results may be summarized as follows:

1. Of three samples about a year old (17, 13, and 12 nionths) all were found to have retained their full activity.

2. Of four sanmples about 18 montlis old $(20,19,18$. and 18 months) one was found to have retained its activity, two were under strength to an extent not exceeding 33 per cent., and one was under strength to an extent exceeding 33 per cent. and not over 66 per cent.

3. Of three samples about 2 years old $(22,23$, and 24 monthis) two were under strength to an extent not exceeding 33 per eent., and one was under strength to an extent excooding 33 per cent. and not over 66 per cent.

4. One sample $2 \frac{1}{3}$ years olk was found to have retained full activity:

5. Of three samples about 3 years olt $(37,37$, and 36 inoniths) one was under strength to an extent not exceed. ing 33 per cent., one to an extent between 33 and 66 per cent., and one to an extent between 66 and 100 per cent.

In view of these results, which in a general way. are concordant with those of others, it is hardly necessary to point out the recessity of prescribing only those tinctures of digitalis which have been standarctized by physiological methods and are not over 12 months old.

Summatity.

1. Nearly 50 per cent. of samples of digitalis macle by manufactaring chemists of repute showed a departure from the average standard of potency.

2. The limits of this variation were from 275 per cent. over strength to -40 per cent. nnder strength. In other words, the effect of a dose of 10 minims might be that of $37 \frac{1}{2}$ minims or of 6 minims.

3. Tincture of digitalis probably retains its full activity for one year, bnt after that period deterioration of its potency to an important extent is likely to take place. 1 Qunt. Journ. of Melt., V., 1912, 1. 297. 2 Mfed. Chron., October,
1911.

\section{LATERAL CURVATURE OF THE SPINE (SCOLIOSIS).}

ANAISIS OF TWO THOUSAND CONSECTTIVE CASES. $B Y$

PACL B. ROTH, M.B., Ch.B.AbERD., F.R.C.S.Exi., LONDON.

THE following aralysis of 2,000 consecutive cases of lateral eurvature of the spine (scoliosis) has been compiled from the notes of cases treated in private practice from July 1885, to June 1899, by the writer's father, Mr. Bernard Roth. The first series of 1,000 cases was published in the latter's book; ${ }^{i}$ the second series of 1,000 was published by the writer in a paper read before the Annual Meeting of the British Medical Association at Birmingham in July 1911, which paper subsequently appeared in the BRITIsh Medical Journal.2 With the exception of reference made to them in a paper in the London Hospital Gazette, ${ }^{3}$ the 2,000 cases are now published together for the first time.

1. SEx.-There were 1,721 females and 279 males-that is, females were affected six times move frequently than

\begin{tabular}{|c|c|c|c|c|}
\hline 1 to 5 years old ... & $\ldots$ & ... & \multicolumn{2}{|c|}{84 cases. } \\
\hline 6 to 10 years old $\ldots$ & $\ldots$ & $\ldots$ & $4 € 4$ &, \\
\hline 11 to 15 years old ... & $\ldots$ & $\ldots$ & 973 & ", \\
\hline to 20 years old ... & $\ldots$ & $\ldots$ & 343 & ," \\
\hline to 30 years old ... & $\ldots$ & $\ldots$ & 105 & $\because$ \\
\hline to 40 years old ... & ... & $\ldots$ & 26 & , \\
\hline or more years old & $\ldots$ & $\ldots$ & 5 & , \\
\hline
\end{tabular}
males.

2. AGE.-The age is taken from the time when the deformity was first noticed.

Thus in 89 per cent. the deformity was first noticed between the ages of 6 and 20 , and in 72 per cent. between the ages of 6 and 15 .

3. HEREDITY.-573 cases, or 28.5 per cent., had blood relations also suffering from scoliosis. Particular's werc obtained of 93 families in whom 3 or nore menbers vere

\begin{tabular}{|c|c|c|c|c|}
\hline $\begin{array}{l}\text { Variety.-Description, } \\
\text { : }\end{array}$ & & Name. & $\begin{array}{l}\text { No. of } \\
\text { Cases. }\end{array}$ & $\begin{array}{c}\text { Per- } \\
\text { centage. }\end{array}$ \\
\hline 1. Whole spine convex to left $\ldots$ & $\ldots$ & Ordinary C & 1,085 & 54.0 \\
\hline $\begin{array}{l}\text { 2. Upyer (dorsal) curve to right) } \\
\text { Lower (lumbar) curve to left }\end{array}$ & $\cdots$ & Reversed S & 618 & 31.0 \\
\hline 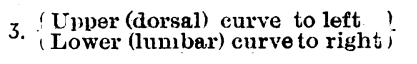 & $\cdots$ & Ordinarys & 123 & 6.0 \\
\hline 4. Whole spine convex to right ... & $\cdots$ & Reversed C & 122 & 6.0 \\
\hline 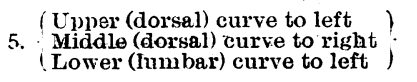 & $\cdots$ & $\underset{\text { Opsilon }}{\text { Ordinary }}$ & 48 & 2.4 \\
\hline 6. $\left.\begin{array}{l}\text { Cpper (dorsal) eurve to right } \\
\text { Middle (dorsal) curve to left } \\
\text { Lower (lumbar) curve to right }\end{array}\right\}$ & $\cdots$ & $\begin{array}{l}\text { Reversed } \\
\text { ipsilon }\end{array}$ & 4 & 0.2 \\
\hline
\end{tabular}
affected ; in 23 of these, 4 or more member's were affected.

4. Deformity (Variety).--Viewing the spine from befind, six varieties of deformity were met with :

In the "reversed $S$ " and "ordinary $S$ " varieties the upper curve with but few exceptions was confined to the dorsal region, and the lower curve to the lumbar region.

Similarly, in the "ordinary ipsilon" and "reversect ipsilon" varieties, the two upper carves with but few exceptions were confined to the dorsal region, and the lower curve to the lumbar region.

5. Deformity (Degree).-The cases were also divided into two groups, the "postural" and the "osseors." The cases with "osseous" deformity were diviled into four subgroups, accopding as the deformity was " a trace," "moderate," " severe," or." extreme." 
Thus, in the first thousand:

TABLE I.

\begin{tabular}{|c|c|c|c|c|c|c|}
\hline \multirow{2}{*}{ Variety. } & \multirow{2}{*}{$\begin{array}{l}\text { Postural } \\
\text { (that is, } \\
\text { no Bony } \\
\text { De- } \\
\text { formity). }\end{array}$} & \multicolumn{4}{|c|}{$\begin{array}{c}\text { Osseous } \\
\text { (that is, with Bony Deformity } \\
\text { due to Vertebral Rotation). }\end{array}$} & \multirow{2}{*}{$\begin{array}{c}\text { Total } \\
\text { (Pos- } \\
\text { tural and } \\
\text { Osseous). }\end{array}$} \\
\hline & & Trace. & $\begin{array}{l}\text { Mode- } \\
\text { rate. }\end{array}$ & Severe. & Extreme & \\
\hline 1. Ordinary $\mathrm{C}$ & 81 & 104 & 276 & 61 & 1 & 523 \\
\hline 2. Reversed $\mathrm{S}$ & 1 & 21 & 152 & 121 & 34 & 329 \\
\hline 3. Ordinary $\mathrm{S}$ & 2 & 7 & 23 & 10 & 3 & 45 \\
\hline 4. Reversed C & 13 & 8 & 32 & 16 & 3 & 72 \\
\hline \multirow{3}{*}{$\begin{array}{c}\text { 5, Ordinary } \\
\text { ipsilon } \\
\text { 6. Reversed } \\
\text { ipsilon }\end{array}$} & - & 1 & 13 & 14 & - & 28 \\
\hline & - & - & 1 & 1 & 1 & 3 \\
\hline & 97 & 141 & 497 & 223 & 42 & 1,000 \\
\hline
\end{tabular}

In the second thousand :

TABLE II.

\begin{tabular}{|c|c|c|c|c|c|c|}
\hline \multirow{2}{*}{ Variety. } & \multirow{2}{*}{$\begin{array}{l}\text { Postural } \\
\text { (that is, } \\
\text { no Bony } \\
\text { De- } \\
\text { formity). }\end{array}$} & \multicolumn{4}{|c|}{$\begin{array}{l}\text { Osseous } \\
\text { (that is, with Bony Deformity } \\
\text { due to Vertebral Rotation). }\end{array}$} & \multirow{2}{*}{$\begin{array}{l}\text { Total } \\
\text { (Pos- } \\
\text { tural and } \\
\text { Osseous). }\end{array}$} \\
\hline & & Trace. & $\begin{array}{l}\text { Mode- } \\
\text { rate. }\end{array}$ & Severe. & Extreme & \\
\hline 1. Ordinary C & 69 & 75 & 365 & 47 & 6 & 562 \\
\hline 2. Reversed S & 3 & 19 & 122 & 120 & 25 & 289 \\
\hline 3. Ordinary $\mathbf{S}$ & - & 7 & 44 & 20 & 7 & 78 \\
\hline 4. Reversed C & 10 & 5 & 25 & 9 & 1 & 50 \\
\hline \multirow{3}{*}{$\begin{array}{l}\text { 5. Ordinary } \\
\text { ipsilon } \\
\text { 6. Reversed } \\
\text { ipsilon }\end{array}$} & 一 & - & 9 & 10 & 1 & 20 \\
\hline & - & - & - & 1 & - & 1 \\
\hline & 82 & 106 & 565 & 207 & 40 & 1,000 \\
\hline
\end{tabular}

Combining the results in Tables I and II, the following figures are obtained for the 2,000 cases :

TABLE III.

\begin{tabular}{|c|c|c|c|c|c|c|}
\hline \multirow{2}{*}{ Variety. } & \multirow{2}{*}{$\begin{array}{l}\text { Postural } \\
\text { (that is, } \\
\text { no Bony } \\
\text { De- } \\
\text { formity). }\end{array}$} & \multicolumn{4}{|c|}{$\begin{array}{l}\text { Osseous } \\
\text { (that is, with Bony Deformity } \\
\text { due to Vertebral Rotation). }\end{array}$} & \multirow{2}{*}{$\begin{array}{l}\text { Total } \\
\text { (Pos- } \\
\text { tural and } \\
\text { Osseous). }\end{array}$} \\
\hline & & Trace. & $\begin{array}{l}\text { Mode- } \\
\text { rate }\end{array}$ & Severe. & Extreme & \\
\hline 1. Ordinary $\mathrm{C}$ & 150 & 179 & 641 & 108 & 7 & 1,085 \\
\hline 2. Reversed $\mathbf{S}$ & 4 & 40 & 274 & 241 & 59 & 618 \\
\hline 3. Ordinary $\mathbf{S}$ & 2 & 14 & 67 & 30 & 10 & 123 \\
\hline 4. Reversed C & 23 & 13 & 57 & 25 & 4 & 122 \\
\hline \multirow{3}{*}{$\begin{array}{l}\text { 5. Ordinary } \\
\text { ipsilon } \\
\text { 6. Reversed } \\
\text { ipsilon }\end{array}$} & - & 1 & 22 & 24 & 1 & 48 \\
\hline & - & - & 1 & 2 & 1 & 4 \\
\hline & 179 & 247 & 1,062 & 430 & 82 & 2,000 \\
\hline
\end{tabular}

6. PaIN.-In 916 cases pain was present; slight in 282, moderate in 250 , severe in 384 .

7. Flat-Foot.-This was present in 1,225 cases. In 933 of these cases the arch was restored by standing on tiptoe. In 292 cases the arch was not so restored-that is, they were cases of severe flat-foot.

In the book and articles cited will be found a full explanation of the terms used in this analysis.

\section{REFERENCES.}

1 T'reatment of Lateral Curvature of the Spine. By Bernard Roth. Second Edition. H. K. Lewis. 1899. 2 Report on a Thousand Consecutive Cases of Scoliosis, British MEDrcaL JOVRNAL, September 2nd,
1911.3 Paper on Scoliosis, London Hospital Gazette, December, 1911.

\section{LEFT-SIDED SUBPHRENIC ABSCESS DUE TO PERFORATED DUODENAL ULCER.}

\author{
BY
}

CHARLES R. BOX, M.D., F.R.C.P.

PHYSICIAN, WITH CHARGE OF OUT-PATIENTS, ST. THOMAS'S HOSPITAL; AND PHISICIAN TO THE LONDON FEVER HOSPITAL.

THE following is an account of a case of subphrenic abscess, consequent upon rupture of a duodenal ulcer, which in many respects shows a striking similarity to that narrated by Dr. H. D. Rolleston in the JouRNAL of Febrtiary 24th.

In both instances the abscess was left-sided, in both it was duodenal in origin, and in each case free gas was found to the right of the falci'orm ligament of the liver and purulent fluid to its left. My patient, however, was a young woman, his a man somewhat advanced in years.

A female servant, aged 23, was admitted to St. Thomas's Hospital on January 26th, 1899, and, in the absence of Dr. Sharkey, came under my care.

The history obtained was meagre, on account of her serious condition. We ascertained that she had never suffered from haematemesis or melaena but was subject to constipation, the bowels acting very irregularly. Six weeks prior to her admission she was laid up for three or four days with what was supposed to be pleurisy. She made a partial recovery, and went to posed to be pleurisy. She made a partial recovery, and went to enced severe pain in the abdomen and felt very ill. She was kept in bed for a week under medical advice, and at the end of that time was sent up to hospital as a case of "pneumonia with pleurisy." There had been no vomiting, the bowels had acted freely, and plenty of urine was passed.

When admitted, she was found to be of good physique, but extremely collapsed and slightly cyanosed. Her pulse-rate was extremely collapsed and slightly cyanosed. Her pulse-rate was
156 , the respirations were 58 , and the temperature $99.2^{\circ}$. Her complaint was of pain in the left side of the thorax and in the abdomen.

The belly was tender and distended; its movements were in abeyance. The liver dullness, internal to the nipple line, was replaced by resonance. The flanks showed slight signs of fluid. In the lower left axilla the percussion note was dull, and this dullness merged with dullness in the left flank. The breath sounds at the base of the left lung were suppressed and a few crepitations audible.

The condition of the patient was very bad. No prolonged examination was possible, and no exploratory operation could be undertaken. She died within twenty-four hours.

\section{Necropsy.}

At the necropsy a considerable amount of free gas was found in the peritoneal cavity. There was but slight generalized peritonitis, and the lesser sac had escaped infection.

Under the left wing of the diaphragm and around the spleen lay an old abscess cavity, the walls of which were lined by a thin grex exudate. The abscess extended along the upper surface of the liver as far as the falciform ligament, by which it was limited to the right. It was shut off from the lower abdomen by the mesocolic shelf and costo-colic fold. Thus on the right side of the falciform ligament was free gas, on the left side pus.

The duodenum was surrounded by adhesions. On its anterior wall, immediately beyond the pyloric ring, was a small perforation which lay in the base of an ulcer the size of a threepenny piece. The ulcer had shelving walls.

The lower lobe of the left lung was entirely collapsed, and it was easy to trace the extent to which the uplifted diaphragm had brought the walls of the pleural sinus together; the apposed portions of the pleura were anaemic and the parts above congested. The upper limit of contact was almost horizontal round the thorax, and its level corresponded accurately to the lower margin of the fifth rib in the axillary line.

When discussing his case Dr. Rolleston remarks on the rarity of left-sided subphrenic abscess as a sequel to duodenal perforation, and quotes some remarks from an address I gave on the watersheds of the peritoneum. ${ }^{1}$ The case related above was one of a number I had before me when I prepared that address, and was the instance on which my remark as to leftward spread was based. It was the first in which $I$ had found a left subphrenic abscess consequent on duodenal ulcer, and is the only one in which I have seen such a strictly localized left-sided collection result. I have, however, my post-mortem notes on another patient, a man aged 25, who was under the care of Dr. Sharkey, also in 1899, and in whom a ruptured duodenal ulcer caused an accumulation of sour and turbid fluid under the left wing of the diaphragm and also in the pelvis.

The factor which determines the gravitation of the infective fluid in such cases is the relation which the 